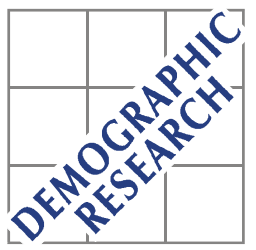

Demographic Research a free, expedited, online journal of peer-reviewed research and commentary in the population sciences published by the Max Planck Institute for Demographic Research Konrad-Zuse Str. 1, D-18057 Rostock · GERMANY www.demographic-research.org

DEMOGRAPHIC RESEARCH

VOLUME 26, ARTICLE 11, PAGES 239-252

PUBLISHED 28 MARCH 2012

http://www.demographic-research.org/Volumes/Vol26/11/

DOI: 10.4054/DemRes.2012.26.11

Reflexion

\title{
The mystery of Japan's missing centenarians explained
}

\author{
Yasuhiko Saito \\ Vanessa Yong \\ Jean-Marie Robine
}

(C) 2012 Yasuhiko Saito, Vanessa Yong \& Jean-Marie Robine.

This open-access work is published under the terms of the Creative Commons Attribution NonCommercial License 2.0 Germany, which permits use, reproduction \& distribution in any medium for non-commercial purposes, provided the original author(s) and source are given credit.

See http:// creativecommons.org/licenses/by-nc/2.0/de/ 


\section{Table of Contents}

$\begin{array}{lll}1 \text { Introduction } & 240\end{array}$

2 Background $\quad 240$

3 Missing centenarians verification by the Japanese government 241

$4 \quad$ Sources of information on centenarians in Japan 243

5 Possible causes for the missing centenarians 246

$\begin{array}{lll}6 & \text { Impact on official statistics } & 248\end{array}$

$\begin{array}{lll}7 & \text { Conclusion } & 249\end{array}$

8 Acknowledgements 249

$\begin{array}{ll}\text { References } & 250\end{array}$

Appendix: BBC new report on missing centenarians in Japan 251 


\title{
The mystery of Japan's missing centenarians explained
}

\author{
Yasuhiko Saito ${ }^{1}$ \\ Vanessa Yong ${ }^{2}$ \\ Jean-Marie Robine ${ }^{3}$
}

\begin{abstract}
This report elucidates the issue of Japan's missing centenarians, which was uncovered in 2010. We provide the latest figures from verification efforts, discuss sources of centenarian information in Japan, examine possible causes, and evaluate the effect of the missing centenarians on official statistics. In Japan 234,354 people registered before 1910 remained on the family registers in 2010 , without being crossed out. They would have been 100 years old at least and represent $0.5 \%$ of the births recorded between 1872 and 1910. The impact of this group on life expectancy statistics, however, is effectively nil.
\end{abstract}

\footnotetext{
${ }^{1}$ Professor, Advanced Research Institute for the Sciences and Humanities (ARISH), Nihon University, 12-5 Goban-cho, Chiyoda-ku, Tokyo 102-8251, Japan. Tel: +81-3-5275-9603. Fax: +81-3-5275-9204. E-mail: saito.yasuhiko@nihon-u.ac.jp.

${ }^{2} \mathrm{PhD}$, Advanced Research Institute for the Sciences and Humanities (ARISH), Nihon University, Japan.

${ }^{3} \mathrm{PhD}$, National Institute on Health and Medical Research, INSERM, France.
} 


\section{Introduction}

The issue of Japan's missing centenarians - which surfaced in the latter half of 2010 and was widely reported in the mass media - generated massive interest and attention among demographers and the general public alike. The discovery of elderly Japanese who had not been seen or whose deaths had gone unreported for years raised critical questions on the accuracy of Japan's life expectancy estimates. It further cast doubts on the world's longest life expectancy - a record that Japan has held for over 25 consecutive years for its long-lived women.

This brief report seeks to elucidate on Japan's missing centenarians and their impact on official life expectancy statistics. We first provide a background on the events leading to the uncovering of Japan's missing centenarians. Next, we discuss the Japanese government's verification efforts and results, as well as the sources of information on centenarians in Japan. Finally, we examine possible causes for the missing centenarians and compute some ratios to evaluate the effect of missing centenarians on statistics.

\section{Background}

On 10 September 2010 the British Broadcasting Corporation (BBC) Asia-Pacific news sensationally reported on missing Japanese centenarians under the headline More than 230,000 Japanese centenarians 'missing' (see Appendix) (BBC News Asia Pacific 10 September 2010). This huge news report followed earlier events from late July when an elderly Japanese man, Mr. Sogen Kato, was found mummified in his home. He would have been 111 years old if he were still alive. It was later found that Mr. Kato had died around 1980. Mr. Kato's wife was a teacher and was eligible for a pension, but she died in 2004. The couple's daughter and granddaughter had never reported Mr. Kato's death and continued to receive his survivor's pension.

The revelation of this first fraud case on 28 July 2010 prompted local government officials to begin checking on their elderly residents through house visits and attempts to meet in person. On 2 August 2010 it was found that the oldest woman in Tokyo, Ms. Fusa Furuya, aged 113 if still alive, had not been seen by her daughter since the 1980s.

These discoveries - in a country where the elderly are traditionally revered and well taken care of - triggered media frenzy, with the Japanese media reporting missing centenarians every day and the foreign media quickly picking up on this newsworthy story. Concurrently, the Japanese government stepped up its verification efforts. 


\section{Missing centenarians verification by the Japanese government}

Using the Resident Registry System coupled with home visits, local governments and their municipal officials conducted the verification of missing centenarians in their respective areas of jurisdiction. According to preliminary information released by the Ministry of Health, Labour, and Welfare (MHLW) on 27 August 2010, there were 271 missing centenarians. Municipalities provided additional information by October 2010, leading to another 313 missing centenarians, bringing the total at that point to 584 . Among the 271 first reported, 25 were receiving pensions at the time. Follow-up investigations revealed that 2 were still alive, and 23 were not located. Of the other 313 missing centenarians, 52 were still receiving pensions. Further investigations found that 29 people were still alive, 1 person was reported dead, and 22 people were not located. This information was released by MHLW on 4 February 2011.

Table 1 shows the verification of the number of missing centenarians by prefecture as of 4 February 2011. The largest numbers of missing centenarians came from Osaka (129 missing) and Hyogo (124 missing) prefectures. There were no missing centenarians in 7 of the 47 prefectures of Japan.

Table 1: Verification of the number of missing centenarians by Japanese local governments

\begin{tabular}{|c|c|c|c|c|c|}
\hline \multirow[b]{2}{*}{ Prefecture } & \multicolumn{3}{|c|}{ Verified to be missing } & \multirow{2}{*}{$\begin{array}{c}\text { Number of } \\
\text { Centenarians as of } \\
\text { September } 1,2010\end{array}$} & \multirow{2}{*}{$\begin{array}{c}\text { Prevalence } \\
\text { of Missing } \\
\text { Centenarians }\end{array}$} \\
\hline & $\begin{array}{c}\text { by August } \\
27,2010\end{array}$ & $\begin{array}{c}\text { by October } \\
2010\end{array}$ & Total & & \\
\hline Hokkaido & 9 & 10 & 19 & 2019 & $0.9 \%$ \\
\hline Aomori & 0 & 1 & 1 & 371 & $0.3 \%$ \\
\hline Iwate & 0 & 2 & 2 & 524 & $0.4 \%$ \\
\hline Miyagi & 0 & 5 & 5 & 685 & $0.7 \%$ \\
\hline Akita & 0 & 4 & 4 & 412 & $1.0 \%$ \\
\hline Yamagata & 0 & 0 & 0 & 485 & $0.0 \%$ \\
\hline Fukushima & 0 & 0 & 0 & 698 & $0.0 \%$ \\
\hline Ibaraki & 3 & 14 & 17 & 792 & $2.1 \%$ \\
\hline Tochigi & 1 & 14 & 15 & 531 & $2.8 \%$ \\
\hline Gunma & 4 & 1 & 5 & 715 & $0.7 \%$ \\
\hline Saitama & 3 & 4 & 7 & 1337 & $0.5 \%$ \\
\hline Chiba & 3 & 10 & 13 & 1435 & $0.9 \%$ \\
\hline Tokyo & 11 & 10 & 21 & 3904 & $0.5 \%$ \\
\hline Kanagawa & 4 & 39 & 43 & 2200 & $2.0 \%$ \\
\hline Niigata & 1 & 1 & 2 & 1148 & $0.2 \%$ \\
\hline Toyama & 0 & 0 & 0 & 556 & $0.0 \%$ \\
\hline
\end{tabular}


Saito, Yong \& Robine: The mystery of Japan's missing centenarians explained

Table 1: (Continued)

\begin{tabular}{|c|c|c|c|c|c|}
\hline \multirow[b]{2}{*}{ Prefecture } & \multicolumn{3}{|c|}{ Verified to be missing } & \multirow{2}{*}{$\begin{array}{c}\text { Number of } \\
\text { Centenarians as of } \\
\text { September } 1,2010\end{array}$} & \multirow{2}{*}{$\begin{array}{c}\text { Prevalence } \\
\text { of Missing } \\
\text { Centenarians }\end{array}$} \\
\hline & $\begin{array}{c}\text { by August } \\
27,2010\end{array}$ & $\begin{array}{c}\text { by October } \\
2010\end{array}$ & Total & & \\
\hline Ishikawa & 0 & 0 & 0 & 506 & $0.0 \%$ \\
\hline Fukui & 0 & 11 & 11 & 352 & $3.1 \%$ \\
\hline Yamanashi & 0 & 1 & 1 & 420 & $0.2 \%$ \\
\hline Nagano & 2 & 0 & 2 & 1032 & $0.2 \%$ \\
\hline Gifu & 2 & 6 & 8 & 658 & $1.2 \%$ \\
\hline Shizuoka & 3 & 1 & 4 & 1220 & $0.3 \%$ \\
\hline Aichi & 4 & 4 & 8 & 1561 & $0.5 \%$ \\
\hline Mie & 1 & 4 & 5 & 623 & $0.8 \%$ \\
\hline Shiga & 0 & 4 & 4 & 436 & $0.9 \%$ \\
\hline Kyoto & 0 & 21 & 21 & 1151 & $1.8 \%$ \\
\hline Osaka & 80 & 49 & 129 & 2356 & $5.5 \%$ \\
\hline Hyogo & 119 & 5 & 124 & 1881 & $6.6 \%$ \\
\hline Nara & 1 & 0 & 1 & 494 & $0.2 \%$ \\
\hline Wakayama & 3 & 0 & 3 & 451 & $0.7 \%$ \\
\hline Tottori & 1 & 0 & 1 & 327 & $0.3 \%$ \\
\hline Shimane & 0 & 2 & 2 & 534 & $0.4 \%$ \\
\hline Okayama & 3 & 3 & 6 & 999 & $0.6 \%$ \\
\hline Horoshima & 2 & 0 & 2 & 1427 & $0.1 \%$ \\
\hline Yamaguchi & 0 & 1 & 1 & 821 & $0.1 \%$ \\
\hline Tokushima & 0 & 10 & 10 & 378 & $2.6 \%$ \\
\hline Kagawa & 0 & 0 & 0 & 497 & $0.0 \%$ \\
\hline Ehime & 5 & 10 & 15 & 744 & $2.0 \%$ \\
\hline Kochi & 2 & 7 & 9 & 483 & $1.9 \%$ \\
\hline Fukuoka & 1 & 10 & 11 & 2024 & $0.5 \%$ \\
\hline Saga & 0 & 0 & 0 & 450 & $0.0 \%$ \\
\hline Nagasaki & 0 & 6 & 6 & 722 & $0.8 \%$ \\
\hline Kumamoto & 0 & 1 & 1 & 1018 & $0.1 \%$ \\
\hline Oita & 1 & 0 & 1 & 551 & $0.2 \%$ \\
\hline Miyazaki & 0 & 28 & 28 & 576 & $4.9 \%$ \\
\hline Kagoshima & 2 & 14 & 16 & 1023 & $1.6 \%$ \\
\hline Okinawa & 0 & 0 & 0 & 922 & $0.0 \%$ \\
\hline Total & 271 & 313 & 584 & 44449 & $1.3 \%$ \\
\hline
\end{tabular}

Source: $\quad$ Ministry of Health, Labour, and Welfare, 27 August, 2010. (http://www.mhlw.go.jp/stf/houdou/2r9852000000nks5img/2r9852000000nkul.pdf); Ministry of Health, Labour, and Welfare, 4 February, 2011. (http://www.mhlw.go.jp/stf/ houdou/2r98520000011vyn-img/2r98520000011w04.pdf, http://www.mhlw.go.jp/stf/houdou/2r98520000011vynimg/2r98520000011wph.pdf)

Note: In Japan, the order of prefectures is based on geographical location, generally from North to South, and is used in official statistics. 
From 27 August to 6 September 2010 Japan's Ministry of Justice also investigated another source of information, the Family Register System (Koseki), for missing centenarians. A total of $47,439,848$ out of $52,572,916$ or $90 \%$ of family registers, which include individuals aged 100 and over without a list of changes in address, were checked. The investigation concluded that there were 234,354 missing centenarians, of whom 77,118 would have been aged $120+$, and 884 would have been aged 150+ (Ministry of Justice, Japan 10 September 2010).

The news headlines reported by the BBC, cited earlier, referred to information based on the Family Register System. Below we discuss the various sources where information on centenarians in Japan can be obtained and offer some possible explanations for the missing centenarians. We then evaluate the impact of the missing centenarians on statistics.

\section{Sources of information on centenarians in Japan}

In Japan there are five sources from which information on surviving centenarians can be obtained. (For a full discussion, see Saito (Saito 2010). The first source is the Family Registration System (Koseki), which was started in 1872. The Koseki contains records of births, adoptions, deaths, marriages, and divorces of all family members. When a family member dies the date of death is recorded in the Koseki. Access to the Koseki is restricted to family members.

The second source is the Resident Registry System, which was started in 1914. Like the Koseki, it is also a civil registration system, but one that is based on current residence. The demographic information for all members of a given household, including the address registered in the family register, date of birth, date of death, relationship to the household head, and previous residential addresses, is recorded on a resident's card (Jyumin-hyo). The difference between a Family Register and a Resident Register is that information included in the latter is current and cannot be used to trace family lineage (Saito 2010). Changes in a Resident Register, such as the birth or death of a household member, are supposed to be reflected automatically in a Family Register. Access to the resident registry is limited but not restricted to family members.

The third source of information on centenarians is the census. The census in Japan is a 'de jure' census and is conducted every 5 years on October 1, based on information from the Resident Registry System. According to the latest census, conducted in 2010, there were 43,767 centenarians.

The fourth source is a list of pension recipients maintained by the Japan Pension Service (JPS; Nippon Nenkin Kiko), which is responsible for public pension system operations. JPS's operations are delegated and entrusted by the Ministry of Health, 
Labour, and Welfare. In Japan it is necessary to apply for pension payments once a person becomes eligible. If those who become eligible for receiving a pension do not submit an application form within five years they lose their right to a pension. When the procedures are completed and approved, the name of the pension recipient is added to the pension recipient list, which, therefore, includes centenarians who are still receiving pension payments. Currently not all centenarians are eligible for pensions. Information on how many centenarians are receiving pensions is not readily available.

The fifth and final source of information on centenarians is a centenarian list (Zenkoku Koreisha Meibo) which is based on data from the Resident Registry System, and was published annually in September from 1963 to 2005 by the Ministry of Health, Labour, and Welfare. Since 2006 only the number of 100-year-olds and the total number of centenarians has been released by the Ministry. As of 1 September 2010 information released by the Ministry shows that Japan had 44,449 centenarians - 5,869 men and 38,580 women. All of these centenarians were confirmed to be alive by local government officials. Because the list and the Census were issued at different times, there are differences in the number of centenarians between the two sources. Figure 1 shows the increase in the number of centenarians in Japan from 1963 to 2010, by gender, based on the Zenkoku Koreisha Meibo. 
Figure 1: Number of centenarians in Japan by age and sex

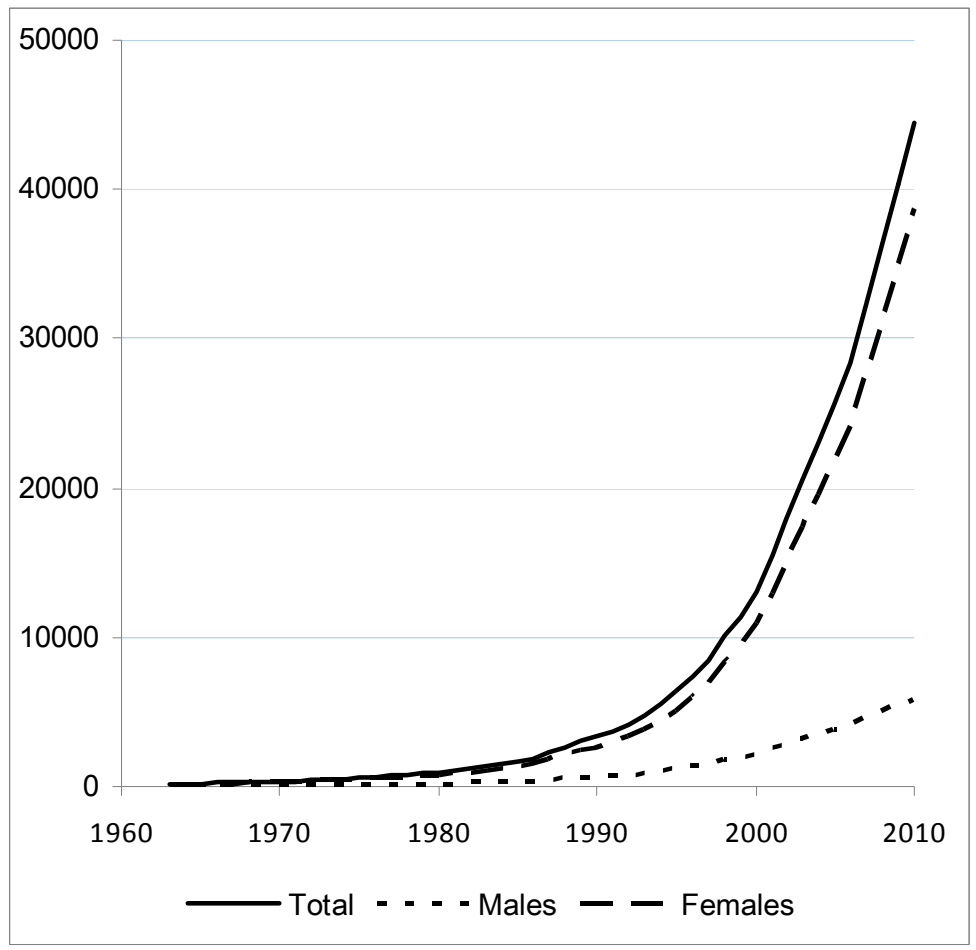

Box: While in Western European countries the number of centenarians has doubled every ten years since the 1960s, in Japan this number has multiplied by 3 or 4 times every decade since 1970. In this context the report of missing centenarians cast doubts on the accuracy of vital statistics in Japan.

Source: $\quad$ Ministry of Health, Labour and Welfare, Japan, 1963-2010. Zenkoku Koureisha Meibo (A list of centenarians in Japan). 


\section{Possible causes for the missing centenarians}

There are several possible explanations to account for the missing centenarians and the difference in numbers in the Family and Resident registration systems. First, death records may not have been updated or were not linked between the two registration systems. When a death occurs family members are mandated by the Family Register Law (Koseki-Ho) to report the event at their local municipal office, which would then add the death record to the Resident Registry System. This information would then be passed on for updating in the Family Register System maintained by the local government. However, the large difference in the reported number of missing centenarians between the two registration systems suggests that the data linkages might be incomplete. Computerised systems have eased data linkages between the two registration systems, but because some municipal offices have yet to computerise the data linkages have to be done manually.

Second, disasters and earthquakes such as the Isewan typhoon and the Great Hanshin-Awaji Earthquake resulted in a large number of people whose records were either not filed accordingly or were lost in the earthquake's aftermath. Third, it is also possible that deaths during the Second World War may not have been reported and that the records still reflect survival status. In Japan authorities cannot delete records from the Family Register System without a death certificate. Table 2 shows the timing of major natural disasters (e.g., earthquakes and typhoons) and World War II, the affected areas, the total number of reported deaths and missing persons, and the ages of those who were born in 1872, 1880, 1890, 1900, and 1910. Those who were born in 1910 were aged 85 when the Hanshin-Awaji Earthquake hit the area. 
Table 2: Dates of major natural disasters and war in Japan, and ages at the time of the disasters of those born in selected years

\begin{tabular}{|c|c|c|c|c|c|c|c|c|c|}
\hline Event & Date & Affected areas & $\begin{array}{l}\text { Total number } \\
\text { of death and } \\
\text { missing }\end{array}$ & Source & $\begin{array}{l}\text { born in } \\
1872 \\
\text { Family } \\
\text { Register } \\
\text { System } \\
\text { started }\end{array}$ & 1880 & 1890 & 1900 & 1910 \\
\hline Great Kanto Earthquake & 1923 & around Tokyo & 142,000 & 2 & 51 & 43 & 33 & 23 & 13 \\
\hline Showa Sanriku Earthquake & 1933 & Iwate & 3,064 & 2 & 61 & 53 & 43 & 33 & 23 \\
\hline Muroto Typhoon & 1934 & esp Osaka & 3,036 & 3 & 62 & 54 & 44 & 34 & 24 \\
\hline World War II & $\begin{array}{l}1939- \\
1945\end{array}$ & Japan & $3,100,000$ & 4 & $67-73$ & $59-65$ & $49-55$ & $39-45$ & 29-35 \\
\hline Tottori Earthquake & 1943 & Tottori & 1,083 & 2 & 71 & 63 & 53 & 43 & 33 \\
\hline Tonannkai Earthquake & 1944 & $\begin{array}{l}\text { Aichi, Mie, } \\
\text { Shizuoka }\end{array}$ & 1,223 & 2 & 72 & 64 & 54 & 44 & 34 \\
\hline Mikawa Earthquake & 1945 & $\begin{array}{l}\text { Chubu, Kinki, } \\
\text { Kanto }\end{array}$ & 2,306 & 2 & 73 & 65 & 55 & 45 & 35 \\
\hline Makurazaki Typhoon & 1945 & $\begin{array}{l}\text { Western Japan } \\
\text { (esp. Hiroshima) }\end{array}$ & 3,756 & 3 & 73 & 65 & 55 & 45 & 35 \\
\hline Nankai Earthquake & 1946 & Chubu & 1,330 & 2 & 74 & 66 & 56 & 46 & 36 \\
\hline Fukui Earthquake & 1948 & Fukui & 3,769 & 2 & 76 & 68 & 58 & 48 & 38 \\
\hline Isewan Typhoon (Vera) & 1959 & $\begin{array}{l}\text { Japan except } \\
\text { Kyushu }\end{array}$ & 5,098 & 3 & 77 & 79 & 69 & 59 & 49 \\
\hline Hanshin-Awaji Earthquake & 1995 & Mainly Hyogo & 6,433 & 1 & 123 & 115 & 105 & 95 & 85 \\
\hline missing centenarians & 2010 & & & & 138 & 130 & 120 & 110 & 100 \\
\hline
\end{tabular}

Source: 1. Hyogo Prefecture homepage: http://web.pref.hyogo.jp/pa20/pa20_000000016.html

2. Seismological Society of Japan homepage: http://wwwsoc.nii.ac.jp/ssj/publications/HIGAl/higai.html

3. Data from Dr. Asanobu Kitamoto's (National Institute of Information) homepage: http://agora.ex.nii.ac.jp/digitaltyphoon/disaster/help/past.html.ja

4. Ministry of Health, Labour and Welfare: http://www.mhlw.go.jp/bunya/engo/seido01/

Fourth, failure to report internal migration to the local governments could also be a possible explanation for the missing centenarians. Individuals from agricultural areas who went to urban areas to work during the winter may have stayed in the urban areas without letting family members know. In addition, international migration, deaths from suicide and accident, and homelessness could be possible reasons for the missing centenarians. 


\section{Impact on official statistics}

To evaluate the impact of the missing centenarians on official statistics we computed some relevant numbers, as shown in Table 3. Assuming that the number based on verifications with the Family Register System is correct, then there are 234,354 missing centenarians. If this number is taken as a proportion of the number of births from 1872 to 1910 , the impact on statistics would be only $0.5 \%$. The effect would be even lower if some of the missing centenarians were born before 1872. Table 3 also presents the proportions for those aged 120+, 100-120, and 150+. As shown, the impact of the missing centenarians on statistics is marginal, if not negligible.

Table 3: Impact of the number of missing centenarians on official statistics

\begin{tabular}{lllll}
\hline & Age & & & \\
\cline { 2 - 5 } & $\mathbf{1 0 0 +}$ & $\mathbf{1 2 0 +}$ & $\mathbf{1 0 0 - 1 2 0}$ & $\mathbf{1 5 0 +}$ \\
\hline Missing centenarians & 234,354 & 77,118 & 157,236 & 884 \\
Number of births & $46,212,825$ & $18,018,050$ & $28,194,775$ & na \\
Between (years) & $(1872-1910)$ & $(1872-1890)$ & $(1890-1910)$ & $\ldots$ \\
Percent & 0.51 & 0.43 & 0.56 & na \\
\hline
\end{tabular}

Even more importantly, according to a press release from the Ministry of Health, Labour, and Welfare's Vital and Health Statistics Division, which compiles the nation's life expectancy statistics, the estimates of life expectancy are computed based on Census data, the Resident Registry, and vital statistics (Fukushi 31 August 2010). Because the 234,354 missing centenarians, as reported, were based on the Family Register System, which was not used as a data source in the life expectancy calculation, their impact on life expectancy statistics is effectively nil.

In addition, we need to evaluate the actual impact of the missing centenarians from the Resident Registry System on Japan's life expectancy estimates. In Japan two types of official life tables are published: complete life tables every five years and abridged life tables every year. The complete life tables are computed based on population census counts and, therefore, the effect of missing centenarians is almost nil. However, the 584 missing centenarians reported in 2010 would have some impact on the abridged life tables if these data were used to compute them. The 2010 abridged life tables for Japan published by the Ministry of Health, Labour, and Welfare state that they have used data up to age 97 for males and 102 for females. Although there is no way of knowing how many of the 584 missing centenarians are female and less than 102 years old, the impact of the missing centenarians is definitely smaller than what the 584 missing centenarians represent. The impact on life expectancy estimates of missing 
nonagenarians in the Resident Registry System might be larger, although we were unable to find the statistics to compute the actual impact. Nevertheless, we tried to estimate by assuming 5\% higher mortality rates for females aged 90 and above in 2010 . The estimated effect is 0.21 years at age 90 (5.76 vs. 5.55) and 0.1 year at birth (86.39 vs. 86.29).

\section{Conclusion}

To conclude, we have elucidated the discussion on Japan's missing centenarians - an issue that has garnered much attention as well as concern regarding the validity of Japan's life expectancy statistics. As explained in this article, these concerns are misplaced. However, they have lifted the veil on an issue which has puzzled demographers for quite some time. How many people registered at birth are never crossed out on the family registers? In Japan 234,354 people registered before 1910 remained on the family registers in 2010 , without being physically identified on the resident registers. This represents $0.5 \%$ of the births recorded between 1872 and 1910 . Is it a good or a bad result? How do we tell? Other countries, such as England and Wales, France, and the Nordic European countries, have quite an old birth registration system originating in the $19^{\text {th }}$ century. It would be interesting to know how many people recorded at birth in these countries were never crossed out with a known date and place of death after, say, 100 or 120 years.

\section{Acknowledgements}

This work was supported by an Academic Frontier Grant (2006-2010) from the Japanese Ministry of Education, Culture, Sports, Science and Technology (MEXT) to the Nihon University. An earlier version of this paper was presented at the $8^{\text {th }}$ Supercentenarian Conference in Madrid, Spain, 27-28 January 2011. We would like to thank the conference participants for their interesting questions and comments. 
Saito, Yong \& Robine: The mystery of Japan's missing centenarians explained

\section{References}

BBC News Asia Pacific (10 September 2010). More than 230,000 Japanese centenarians 'missing'.

Fukushi, Y. (31 August 2010). Life expectancy statistics debated. Yomiuri Shimbun.

Ministry of Justice, Japan (10 September 2010). http://www.moj.go.jp/ MINJI/minji04_00008.html.

Saito, Y. (2010). Supercentenarians in Japan. In: Maier, H., Gampe, J., Jeune, B., Robine, J.M., and Vaupel, J.W. (eds.). Supercentenarians. Heidelberg, Dordrecht: Springer: 75-99. 


\section{Appendix: BBC new report on missing centenarians in Japan}

\section{More than 230,000 Japanese centenarians 'missing'}

More than 230,000 elderly people in Japan who are listed as being aged $\mathbf{1 0 0}$ or over are unaccounted for, officials said following a nationwide inquiry.

An audit of family registries was launched last month after the remains of the man thought to be Tokyo's oldest were found at his family home.

Relatives are accused of fraudulently receiving his pension for decades.

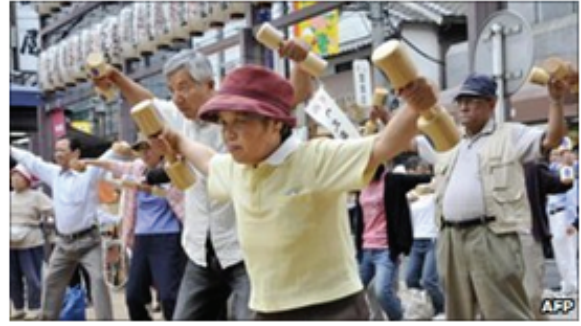

Japanese citizens are famous for their longevity
Officials have found that hundreds of the missing would be at least 150 years old if still alive.

The Justice Ministry said some of those unaccounted for may have died as long ago as World War II, possibly during the post-war turmoil.

Others may have emigrated without reporting their status to local authorities, or relatives simply did not report the deaths.

The inquiry followed the discovery of the mummified remains of Sogen Kato, who was thought to be the oldest man in Tokyo.

However, when officials went to congratulate him on his 111th birthday, they found his 30 -year-old remains, raising concerns that the welfare system is being exploited by dishonest relatives.

Reports said he had received about $9.5 \mathrm{~m}$ yen $(\$ 109,000 ; £ 70,000)$ in pension payments since his wife's death six years ago, and some of the money had been withdrawn.

Japan has one of the world's fastest ageing societies, with one in five over the age of 65 .

Last year's Health Ministry report said Japan had 40,399 people aged 100 or older with known addresses.

\section{Related Stories}

Tokyo's 'oldest woman' is missing Tokyo's 'oldest man' was a corpse 
Saito, Yong \& Robine: The mystery of Japan's missing centenarians explained 